\title{
FIRST-YEAR ACADEMIC PERFORMANCE OF PHARMACY STUDENTS BASED ON HIGH SCHOOL STATUS AND MAJOR
}

\author{
Didiek Hardiyanto Soegiantoro ${ }^{1}$, Holy Rhema Soegiantoro ${ }^{2}$, Gregory Hope \\ Soegiantoro ${ }^{3}$ \\ ${ }^{1}$ Department of Pharmacy, Immanuel Christian University \\ ${ }^{2}$ IPMI International Business School \\ ${ }^{3}$ Padmanaba $3^{\text {rd }}$ State Senior High School Yogyakarta \\ Email: didiek@ukrimuniversity.ac.id,holy.soegiantoro@ipmi.ac.id, \\ gsoegiantoro@gmail.com
}

\begin{abstract}
The purpose of the research is provides a descriptive first-year academic performance of pharmacy students based on high school status and major. This research is a descriptive research with cross-sectional method using all pharmacy students as sample. The results of this research are percentage of pharmacy students from public high schools is $33 \%$ and $67 \%$ from private high schools. The percentage of specialization majors in high school is $6 \%$ pharmacy, $85 \%$ science and $9 \%$ non-science. The academic performance of students from private high schools is better than that of public high schools. Pharmacy majors in high school produce the highest academic performance, meanwhile, non-science majors show the lowest academic performance, the principal results. Conclusions in this research is first-year academic performance for pharmacy students from private high schools is better than public high schools, as well as pharmacy major in high school showing the highest GPA and non-science major showing the lowest GPA.
\end{abstract}

Keywords: academic performance; GPA; public high school, private high school high school major.

\section{Introduction}

High schools in almost every country are distinguished between public and private. Public and private high schools have different management, but are still under strict supervision from the government. The freedom to choose public or private high school is determined by local government autonomy, competition, and sorting system (Kim, 2018). The cost of education in public and private schools is very different because the government provides most of the subsidies in public high schools while private high schools finance almost all of their expenses through tuition payments and donors. Financial management sourced from tuition payments from students and sponsors causes private high schools to show higher cost-effectiveness than public high schools (DeAngelis, 2021). A number of papers have compared the effectiveness of private and public schools in different institutional settings. Many studies have shown that private high schools produce academic performance that is superior to the national exam compared to public high schools. But several other studies have shown the

\footnotetext{
How to cite: $\quad$ Soegiantoro, D. H., Soegiantoro, H. R., \& Soegiantoro, G. H. (2021). First-year Academic Performance of E-ISSN: Pharmacy Students Based on High School Status and Major. Syntax Literate: Jurnal Ilmiah Indonesia, 6(1). 
opposite results, all of which are determined by many different factors from each research setting (Kortelainen \& Manninen, 2019)

The difference in study costs between public and private high schools causes differences in the social level of the family, resulting in differences in the social status and lifestyle of students. Students from families with middle to lower socioeconomic status can get scholarships at private high schools, and vice versa there are students from families with high economic status can enter public schools because they have achievements in academic and non-academic fields (Azaola, 2021).

The use of students' within-school grade point average (GPA) ranking has emerged as a means to increase admission rates of both segregated minorities and highperformance individuals. Almost all colleges and universities request results of studies while in high school at the time of enrollment, therefore public and private compete to produce high GPA outputs. In addition to being high in GPA, prospective students also compete in academic exam scores conducted in general and by individual colleges and universities (Fajnzylber, Lara, \& León, 2019). The higher the ranking of colleges and universities, the level of competition for prospective students who enroll is more and more. The higher the GPA obtained from high school, the greater the opportunity, therefore reputable high schools hold many programs to increase the academic performance of their students so that they are expected to produce high GPA and can pass the selection exam (Sukasni, 2019). The results of research in Japan show that private high school students have lower academic abilities than public high schools. private high school students are generally from a higher social class than public high school students. However, private high school students have greater educational success than public high school students (Nishimaru, 2017). Public and private colleges and universities also determine the level of interest of prospective students to enroll, because private colleges and universities generally charge higher tuition fees than public colleges and universities. universities with a balanced reputation. In addition to cost considerations, prospective students also prefer colleges and universities located in their area of residence to reduce the cost of living outside the city (Lourenço, Sá, Tavares, \& Cardoso, 2020).

Until 2021, pharmacy is still a favorite educational program that is in demand because it still has a large number of job opportunities. The ratio of pharmacists to population in 2020 according to data from the Indonesian Ministry of Health is more than 1:50 compared to doctors which is only 1:25 (Indonesian Ministy of Health, 2021).

Pharmacy education, like medical, requires commitment and high learning performance. The number of assignments and practicums combined with the demands of a comprehensive analysis of various considerations in pharmaceutical services is one of the causes of failure of pharmacy students. A strong foundation in the basic sciences is crucial for students to develop critical thinking skills necessary to deliver patientcentered care (Palmer \& Clegg, 2016) and (Wang, Cruthirds, \& Kendrach, 2018). Early identification of poor-performing and at-risk students and effective intervention are integral to student academic success and self-directed learning. In addition, various efforts have been made from previous studies, including remediation and reassessment with various methods that can improve the competence of graduate pharmacy students (Harmon, Gonzales, \& Fenn III, 2021), as well as by developing various co-curricular activities that can improve leadership skills so as to motivate students to improve academic performance (Fox \& Sease, 2019). Some pharmacy departments have 
implemented an assessment before the student registration process, so as to eliminate students who have difficulty and fail to study (Fox \& Sease, 2019).

This study aims to compare the academic performance of first-year pharmacy students based on several variables determined during high school, namely private or public high school status, high school majors, and academic scores in high school.

\section{Method}

This research is a descriptive research with cross-sectional method. The population and sample of this study were all pharmacy students at Immanuel Christian University from all batches. High school background data was taken from a questionnaire while the first year GPA data was taken from academic data.

\section{Results and Discussion}

The percentage of pharmacy students from public high schools is 33\% and $67 \%$ from private high schools. The percentage of specialization majors in high school is $6 \%$ pharmacy, $85 \%$ science and $9 \%$ non-science.

Table 1

GPA of pharmacy students by high school status

\begin{tabular}{cccc}
\hline & $\begin{array}{c}\text { First } \\
\text { Semester }\end{array}$ & $\begin{array}{c}\text { Second } \\
\text { Semester }\end{array}$ & $\begin{array}{c}\text { First-year } \\
\text { Cumulative GPA }\end{array}$ \\
\hline Private High School & 3.67 & 3.26 & 3.47 \\
Public High School & 3.26 & 3.03 & 3.15 \\
\hline
\end{tabular}

Source: Soegiantoro

Table 1 shows that the academic performance of students from private high schools is better than that of public high schools. This result confirms that although the academic ability of private high school students is lower, it is higher in educational success. Based on the evaluation of the academic guardian lecturers conducted at the end of each semester, students from private high schools generally have a better enthusiasm for learning and discipline than students from public high schools.

The average GPA value from high school is not taken into account in this study because it varies and there is no GPA standardization so that each high school has its own GPA standard and cannot be compared with GPA standards from other high schools. The admissions department can consider the GPA scores from high school but cannot be used to make a student success scale based on the GPA from that high school.

Table 2

GPA of pharmacy students by high school majors

\begin{tabular}{cccc}
\hline & $\begin{array}{c}\text { First } \\
\text { Semester }\end{array}$ & $\begin{array}{c}\text { Second } \\
\text { Semester }\end{array}$ & $\begin{array}{c}\text { First-year } \\
\text { Cumulative GPA }\end{array}$ \\
\hline Pharmacy major & 3.88 & 3.71 & 3.80 \\
\hline Science major & 3.46 & $3 . .24$ & 3.35 \\
Non-Science major & 3.23 & 3.03 & 3.13 \\
\hline \multicolumn{3}{c}{ Source: Soegiantoro }
\end{tabular}

Pharmacy majors in high school produce the highest academic performance because they have been taught basic pharmaceutical knowledge so that they do not 
require adjustment and introduction of pharmaceutical sciences. Meanwhile, nonscience majors show the lowest academic performance because students are not accustomed to using analytical logical thinking patterns while in high school. Colleges and universities certainly want students to have good academic performance, because thus avoiding the risk of failing studies or difficulties in completing their studies. There have been various efforts from the admissions department of the pharmacy faculty to get students with specialization in pharmacy, but most of them after graduating from high school choose to go straight to work because they already have the basic skills to work in pharmacies or hospitals as pharmacist assistants.

\section{Conclusion}

First-year academic performance for pharmacy students from private high schools is better than public high schools, as well as pharmacy major in high school showing the highest GPA and non-science major showing the lowest GPA.

\section{REFERENCE}

Azaola, Marta Cristina. (2021). Social fragmentation and the public-private school divide: the case of high-achieving high schools in Mexico City. Globalisation, Societies and Education, 1-15. Google Scholar

DeAngelis, Corey A. (2021). The cost-effectiveness of public and private schools of choice in Wisconsin. Journal of School Choice, 15(2), 225-247. Google Scholar

Fajnzylber, Eduardo, Lara, Bernardo, \& León, Tomás. (2019). Increased learning or GPA inflation? Evidence from GPA-based university admission in Chile. Economics of Education Review, 72, 147-165. Google Scholar

Fox, Laura M., \& Sease, Julie M. (2019). Impact of co-curricular involvement on academic success of pharmacy students. Currents in Pharmacy Teaching and Learning, 11(5), 461-468. Google Scholar

Harmon, Kiersi S., Gonzales, Alessa D., \& Fenn III, Norman E. (2021). Remediation and reassessment methods in pharmacy education: a systematic review. Currents in Pharmacy Teaching and Learning, 13(1), 81-90. Google Scholar

Kim, Youngran. (2018). The effects of school choice on achievement gaps between private and public high schools: Evidence from the Seoul high school choice program. International Journal of Educational Development, 60, 25-32. Google Scholar

Kortelainen, Mika, \& Manninen, Kalle. (2019). Effectiveness of private and public high schools: Evidence from Finland. CESifo Economic Studies, 65(4), 424-445. Google Scholar

Lourenço, Diogo, Sá, Carla, Tavares, Orlanda, \& Cardoso, Sónia. (2020). Enrolling in Higher Education: The Impact of Regional Mobility and Public-Private 
Didiek Hardiyanto Soegiantoro, Holy Rhema Soegiantoro, Gregory Hope Soegiantoro

Substitution Effects. Journal of Economic Issues, 54(1), 183-197. Google Scholar

Nishimaru, Ryoichi. (2017). The Relationship between High School Sector and Educational Success: Focusing on the Social Background of Private High School Students. International Journal of Japanese Sociology, 26(1), 83-95. Google Scholar

Palmer, Biff F., \& Clegg, Deborah J. (2016). Physiology and pathophysiology of potassium homeostasis. Advances in Physiology Education. Google Scholar

Sukasni, Agnes. (2019). The Implementation And Discovery Of Best Significant Indicators Of High School Quality Particularly Both Quality Process And Output. Science Nature, 2(3), 128-147.Google Scholar

Wang, X. Robert, Cruthirds, Danielle L., \& Kendrach, Michael G. (2018). Effect of an individualized post-examination instructor remediation on pharmacy student performance in a biochemistry course. American Journal of Pharmaceutical Education, 82(6). Google Scholar

\section{Copyright holder:}

Didiek Hardiyanto Soegiantoro, Holy Rhema Soegiantoro, Gregory Hope Soegiantoro (2021)

First publication right:

Syntax Literate: Jurnal Ilmiah Indonesia

This article is licensed under:

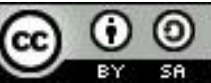

